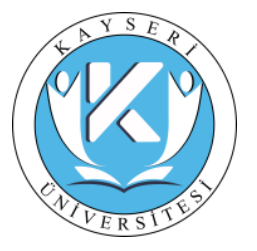

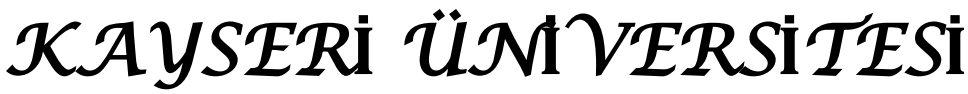 Sosyal Bilimler Dergísi

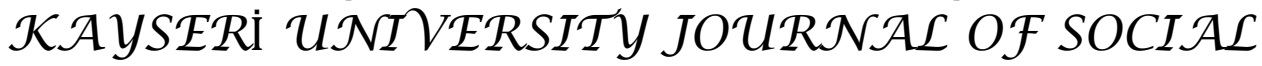 SCIE $\mathcal{N C E S}$
}

\begin{tabular}{|l|l|l|l|l|l|}
\hline Makale Türü & Araştırma makalesi & Yıl & $\mathbf{2 0 2 1}$ & ss. & $\mathbf{2 4 - 4 0}$ \\
\hline Gönderi Tarihi & $\mathbf{0 3 . 0 5 . 2 0 2 1}$ & Cilt & $\mathbf{3}$ & DOI & $\mathbf{1 0 . 5 1 1 7 7 / k a y u s o s d e r . 9 3 2 1 0 9}$ \\
\hline Kabul Tarihi & $\mathbf{2 4 . 0 6 . 2 0 2 1}$ & Say1 & $\mathbf{1}$ & & \\
\hline Online Yayın Tarihi & $\mathbf{3 0 . 0 6 . 2 0 2 1}$ & Ay & Haziran & \\
\hline
\end{tabular}

\section{“Gün Olur Asra Bedel” romanında hâldeki olayların olay örgüsüne nakşedilişi ve romanda anlatım tekniklerinin kullanılışı* $* \Delta$}

\section{In the novel "Gün olur asra bedel", the events in the present are placed into the plot and the use of narrative techniques in the novel}

$\ddot{O} \mathbf{z}$

Cengiz Aytmatov, Kırgız edebiyatının önde gelen isimlerinden olup ünü dünyaya yayılmış bir yazardır. Toplumsal problemlere işık tuttuğu eserleriyle edebiyatımızda yeri dolmayacak şahsına münhasır bir edebiyat insanıdır. Sovyet dönemi yazarı olarak yetişmiş ve eserlerinde Türk'ün Sovyet elinden çektiği zulmü anlatmıştır. Bunu bazen sezdirmeden ve bazen de aleni olarak yapmıştır. Sözünü edeceğimiz, Gün Olur Asra Bedel, Cengiz Aytmatov'un roman türünde tek eseridir. 1980'de kaleme alınmıştır. Aytmatov, Kırgız toplumunun portresini çizmiştir. Gün Olur Asra Bedel'de yazarımız, Kazangap'ın vefat ve defni arasında geçen bir zamandan bahsederken, geriye dönüşlerle birden fazla olaya açıklık getirmiştir. Hâldeki olaylarda yalnızca olup bitenlerin seyri verilmemiş; çeşitli tarihi olaylara, geleneklere, örf-âdetlere değinilerek, Boranlı halkının günlük hayatı ve kültürü verilmiştir. Bu bakımdan Aytmatov edebiyatımıza, oldukça zengin kültür numunelerini bünyesinde toplayan bir eser kazandırmıştır.

Anahtar Kelimeler: Cengiz Aytmatov, Kırgız Edebiyatı, Gün Olur Asra Bedel, Hâldeki Olaylar, Anlatım Teknikleri.

\section{Abstract}

Cengiz Aytmatov is one of the leading names of Kyrgyz Literature and a writer whose reputation has spread around the world. With his works that shed light on social problems, he is a unique literary man whose place can never be filled in our literature. He grew up as a writer of the Soviet period and he wrote about the Turks who were oppressed by Soviets. He sometimes did this secretly and sometimes publicly. Gün Olur Asra Bedel that we are going to talk about is the only genre novel that Cengiz Aytmatov wrote. It was written in 1980. Aytmatov painted the portrait of Kyrgyz society. Our writer clarified more than one event with flashbacks in Gün Olur Asra Bedel by mentioning the time between Kazangap's death and his burial. In the novel, it was given the people of Boranlı's daily life and culture by mentioning some historical events, traditions and customs. Only the course of what is happening is not given in the current events by mentioning some historical events, traditions and customs, the daily life and culture of the people of Boran have been given. In this respect, he brought in a work which has quite wealthy culturel samples in it to our literature.

Keywords: Cengiz Aytmatov, Kyrgyz Literature, Gün Olur Asra Bedel, Current Events, Narrative Techniques.

\footnotetext{
${ }^{\Delta}$ Yazarlar bu çalışmanın tüm süreçlerinin araştırma ve yayın etiğine uygun olduğunu, etik kurallara ve bilimsel atıf gösterme ilkelerine uyduğunu beyan etmiştir. Aksi bir durumda Kayseri Üniversitesi KAYÜSOSDER Dergisi sorumlu değildir.

*Etik kurul izni gerektirmeyen çalışmalardandır.

${ }^{1}$ Tezli Yüksek Lisans Öğrencisi, İstanbul Aydın Üniversitesi, Lisansüstü Eğitim Enstitüsü, Türk Dili ve Edebiyatı Bölümü, suedademir@stu.aydin.edu.tr
} 
Demir, S. (2021). "Gün Olur Asra Bedel" romaninda hâldeki olaylarm olay örgüsüne nakşedílişi ve romanda anlatım tekniklerinin kullanilışı.

\section{Giriş}

Cengiz Aytmatov yalnızca Kırgız Edebiyatı için değil, tüm Türk dünyası edebiyatları için çok büyük öneme sahiptir. Aynı şekilde 1980 tarihinde yazdığı, onun edebî hayatının zirvesi sayılan romanı "Gün Olur Asra Bedel" de aynı öneme sahiptir. Biz bu çalışmamızda, yazarın "Gün Olur Asra Bedel" eserinden vereceğimiz örnekler yoluyla hâldeki olayların olay örgüsüne nasıl yansıdığından ve yazarın eseri kaleme alırken kullandığı anlatım tekniklerinden bahsetmeye çalışacağız. Bu makale ile amacımız, Gün Olur Asra Bedel'in olay örgüsünü, hâldeki olayları oluşturan ana iskeleti görünür k1labilmektir. Bu unsurların somut delillerle anlaşılır kılınmasının önemli olduğunu düşünüyoruz. Çalışmamızda, metin tahlilleri yöntemini kullandık ve çalışmamızın üçüncü bölümünde anlatım tekniklerini tespit ederken, yazarın yıldızlarla ayırdığı kısımları baz aldık. Aynı zamanda yapı unsuru olarak olay örgüsünü esas aldık. Çalışmamızı hazırlarken bazı hipotezlerden yola çıktık. Bunlar; "Gün Olur Asra Bedel”de anlatım tekniklerinin büyük bir kısmının kullanıldığı, hâldeki olayların olay örgüsünün ana iskeletini oluşturduğu, Cengiz Aytmatov'un yaşadığı coğrafyayı eserinde yansıttı̆̆ı, eserde mekân tasvirlerinin oldukça fazla olduğudur. Veri toplama tekniği olarak metin tahlili yöntemini kullandığımız çalışmamızda anlatım tekniklerinin incelenmesi, Cengiz Aytmatov'un "Gün Olur Asra Bedel" eserindeki 86-112 arası sayfalarla sınırlıdır. Bu sayfa aralığı romanın Ötüken Yayınları'ndan çıkan 58. baskısına göre belirlenmiştir. Çalışmamız etik kurul kararı gerektirmeyen ve telif hakkı düzenlemelerine uyulan bir çalışmadır.

\section{Cengiz Aytmatov}

\subsection{Cengiz Aytmatov'un yaşamı}

Cengiz Aytmatov, Kırgızistan Şeker Köyü'nde, 1928'de dünyaya gelen bir Kırgız yazarıdır. Bu köy Bişkek'e bağlıdır. Annesi Nagima Hamzayevna Aytmatov, babası ise Törekul Aytmatov'dur. Aytmatov'un babası, Sovyet rejiminin haksız yaptırımlarıyla kurban ettiği nice aydından birisidir. Annesi Aytmatov'u ve onun kardeşlerini tek başına büyütmüştür. Babasız bir erkek çocuk olarak Cengiz Aytmatov, daha çok küçük yaşlarda çalışma hayatına atılmak zorunda kalmıştır. 1953'te Veterinerlik Fakültesini bitirmiş, ardından Kırgızistan Tarım Enstitüsü’ne devam etmiştir.

Aytmatov, edebî hayatına atılınca bu yönde de eğitimler almış, Moskova'da Gorki Edebiyat Enstitüsü'ne gitmiştir. 1958'de ise Moskova Üniversitesi, Edebiyat Fakültesi'nde eğitim görmeye başlamıştır. Zor bir yaşamı olan Aytmatov'un, babasının siyasi muhalif durumundan dolayı çoğu kez bursları kesilmiştir. Dönemin siyasetindeki değişmeler sebebiyle hem Kırgız hem de Rus yazarlar arasında adı anılmıştır. Maddi-manevi zorluklar onu yıldırmamış, Türkçe'nin en önemli yazarlarından biri olmuş, çeşitli ödüller kazanmıştır.

9 Haziran 2008'de rahatsızlanan Aytmatov, Almanya Nürnberg'de hastaneye kaldırılmış ve orada vefat etmiştir (Aytmatov, 2018).

Araştırmacıların genel görüşü, Cengiz Aytmatov'un isminin Moğolca bir kelime olan "tenggis" den geldiği ve bu kelimenin "deniz" manasını taşıdığı yönündedir. Soyadındaki -ov ise Slav kültürüyle alakalıdır (Tulum, 2014, ss. 92-94).

Cengiz Aytmatov ile 73 senelik bir geçmişi olduğunu ileten ve kendisi için Aytmatov'un öneminden bahseden Prof. Dr. Osmanakun İbrayimov'un, 19 Kasım 2018'de İstanbul Aydın Üniversitesi'nde, “Doğumunun 90. Yılında Cengiz Aytmatov Töreni”"nde verdiği bilgilere göre; Sovyetler'in Cengiz Aytmatov'un hayatında büyük bir etkisi olmuştur. Sovyetler devrinin Kırgızlar üzerindeki etkisi genel anlamda pozitif yöndedir. Cengiz Aytmatov' un hayatı hep mutlu ve başarılıymış gibi gözükse de özellikle babasının vefatından sonraki hayatı zorluklarla geçmiştir. Aytmatov, Sovyetler birliğine bağlı bir yazar olmasının yanında, son derece eleştirel bir yazardır. Kırgızistan'ın bağımsızlığını kutlamış ve bu bağımsızlığı destekleyen bir Kırgız yazarı olmuştur (İstanbul Aydın Üniversitesi, 2018). 
Kayseri Üniversitesi Sosyal Bilimler Dergísí. Cïlt 3, Sayi: 1, Haziran 2021, 24-40

Kayseri University Journal of Social Sciences. Vol 3, No: 1, June 2021, 24-40

\subsection{Cengiz Aytmatov'un sanat anlayıșı}

Cengiz Aytmatov, edebî hayatına bir Sovyet yazarı olarak başlamıştır. İlkokulu kendi köyünde okuyan Aytmatov'un edebî gelişiminde, babaannesi Ayıkman Hanım'ın kendisine okuduğu ninni ve masalların etkisi büyüktür. Aytmatov'u sadece Sovyet insanı değil, tüm dünya severek okumuştur. Kırgızları ve edebiyatlarını dünyaya sunan da Cengiz Aytmatov'dur. Bu yönüyle ayrıca öneme sahiptir. Halkının kültürünü eserlerinde kullanmış ve duyurmuş̧tur (Dıykanbayeva, 2015, ss. 170-172).

Aytmatov, eserlerini kurgularken alelade konulardan yola çıkmamıştır. Onun eserlerinin bir derdi vardır. Sovyet yazarı olarak kendi zor yaşamından beslenmiş ve adeta içinde bulunduğu toplumun aynası olacak eserler kaleme almıştır. Cengiz Aytmatov, Kırgız coğrafyasından çıkıp sadece Türkiye'de tanınmamış, şöhreti tüm dünyaya yayılan bir yazar olmuştur. Cengiz Aytmatov sevgi doludur ve bir aşk yazarıdır. Bu eserlerinde kendini gösterir. Kahramanlarına karşı derin bir merhamet içindedir.

Prof. Dr. Osmanakun İbrayimov'un, yine 19 Kasım 2018'de İstanbul Aydın Üniversitesi, “Doğumunun 90. Yılında Cengiz Aytmatov Töreni”nde verdiği bilgilere göre; Aytmatov, Sovyetler'in Kırgızlar üzerindeki etkisini bildiği için, tüm bunları eserlerinde yansıtmıştır. Onun eserleri bu yönüyle daha çok dramatik ve trajedi ile sonlanmıştır. Cengiz Aytmatov, Sovyet İmparatorluğu'nun son yazarı, Bağımsız Kırgız Cumhuriyeti'nin ise ilk yazarı olmuştur (İstanbul Aydın Üniversitesi, 2018).

Prof. Dr. Kazım Yetiş'in, 19 Kasım 2018'de İstanbul Aydın Üniversitesi, "Doğumunun 90. Yılında Cengiz Aytmatov Töreni"ndeki "Cengiz Aytmatov Üzerine Bazı Dikkatler” isimli konuşması, Aytmatov'un bir yazar olarak önemini müthiş derecede vurgulamıştır.

Türk ve dünya edebiyatının bu büyük kaleminin eserleri; kendi hayatından, çevresinden, Kırgız kültüründen derin izler taşır. Biliyoruz ki büyük destan Manas’ı her zaman okumuştur. Kaynak olarak da kullanmıștır. Hatta onu dünyaya tanıtmıștır. Burada şuna dikkatinizi çekmek istiyorum: Bir sanatkâr içinde yaşadığı toplumu, onun gerçeklerini edebî esere aksettirdiği ölçüde başarılı olur (İstanbul Aydın Üniversitesi, 2018).

Sayın Kazım Yetiş, bu konuşmasında Cengiz Aytmatov'un eserlerindeki lirizm üzerinde de durmuş ayrıca eserlerindeki olay örgüsünün çoklukla monologlar ve iç monologlardan oluştuğuna değinmiştir.

\subsection{Cengiz Aytmatov'un eserleri}

Cengiz Aytmatov'un eserlerinden bahsederken, öncelikle eserlerini kronolojik sırasına göre vermeyi uygun gördük:

a. Hikâye ve Romanları:

Betme-Bet, 1957 (Yüz Yüze)

Camilya, 1958 (Cemile)

Toolar Cana Talaalar Bayanı, 1961 (Steplerden ve Dağlardan Hikâyeler)

Samançının Colu, 1962-63 (Toprak Ana)

Kizıl Alma,1964 (Al Elma)

Canıbarım Gülsarı,1966 (Elveda Gülsarı)

Svidanie s Sınom, 1969 (Oğulla Buluşma)

Ak Kemi, 1970 (Beyaz Gemi)

Deniz Boylop Cortkon Ala Döböt, 1971 (Deniz Kıyısında Koşan Ala Köpek)

Atadan Kalgan Tuyak, 1971-72 (Askerin Oğlu)

Ete Kelgen Turnalar, 1975-76 (Erken Gelen Turnalar / Sultanmurat)

Kılım Karıtar Bir Kün, 1980-81 (Gün Uzar Yüzyıl Olur / Gün Olur Asra Bedel)

Kıyamat, 1985 (Dişi Kurdun Rüyaları)

Ak Caan, 1990 (Beyaz Yağmur)

Çıngıs Handın Ak Bulutu, 1990 (Cengiz Han'a Küsen Bulut)

Plaç Pereletnoy Ptitsi, 1990 (Göçmen Kuşun Çığlığı / Yıldırım Sesli Manasçı)

Kassandra Tamgası, 1995 (Kassandra Damgası)

Toolor Kulaganda, 2007 (Dağlar Devrildiğinde / Ebedî Nişanlı) 
Demir, S. (2021). "Gün Olur Asra Bedel" romaninda hâldeki olaylarm olay örgüsüne nakşedilişi ve romanda anlatım tekniklerinin kullantlışı.

b. Tiyatrolar1:

Fudziyamadagı Katır Tün, 1975 (Fuji Dağının Zirvesi)

Noç Vospominanny o Sokrate, 2000 (Sokrat'ı Anma Gecesi)

c. Hatıra/Sohbetleri:

Küz Basındagı Anşının Zarı, 1997 (Kuz Başında Avcının Çığlığı)

Kindheit in Kirgisien, 1998 (Çocukluğum, Zürich)

d. Düşünce Yazıları:

Manas Atanın Ak Kar-Kök Muzu

Car Buyunda Bozdop Turğan Ançının İyi (Kahraman, 2016).

Cengiz Aytmatov çok iyi eğitim almış çok çeşitli alanlarda çalışmış biridir. Onun eserleri tüm halklarca sevilerek okunmuştur. Ünü dünyaya yayılmış bir yazardır. Eserleri 170 civarında dile çevrilmiş böylece her yere ulaşmıştır. Aytmatov, "Cemile" isimli hikâyesinin Fransız bir şair tarafindan Fransızca' ya tercüme edilmesiyle büyük bir şöhret yakalamıştır. "Cemile” için en güzel aşk hikâyesi görüşü yine bu şair tarafından dile getirilmiştir. Onun ilk eseri, 1952'de Pravda gazetesinde yayımlanan "Gazeteci Cyuda"dır.

Yukarıda sıraladığımız eserlerinden anlaşıldığı gibi Aytmatov oldukça velut bir yazardır. Biz, makalemizde onun "Gün Olur Asra Bedel" isimli romanı üzerinde duracağız.

Her yazar eserlerini kaleme alırken, öyle ya da böyle öz yaşamından yararlanır. Cengiz Aytmatov da bu yazarlardan biridir. "Gün Olur Asra Bedel" ve "Cengiz Han'a Küsen Bulut" isimli romanlardaki Abutalip isimli karakterin yaşadıkları, adeta Cengiz Aytmatov'un babası Törekul Aytmatov'un başına gelenleri hatırlatır. Cengiz Aytmatov'un annesi ise, "Gün Olur Asra Bedel"deki kocası tutuklanınca çocuklarını yalnız büyüten Zarife'yi hatırlatır. Aytmatov bu romanları yazdığında babasının başına gelen bu acı sondan, babasının bu şekilde öldürüldüğünden habersizdir. Aynı şekilde "Beyaz Gemi" isimli romanında da anne-baba hasreti çeken çocuk, Aytmatov'un kendisi gibidir. Bu şekilde Aytmatov'un eserlerinin hemen hemen hepsinde yaşamından izler bulunur. Onun eserleri bu yönüyle otobiyografik yönü çok baskın eserlerdir (Yılmaz, 1998).

Cengiz Aytmatov çok usta bir yazardır. "Gün Olur Asra Bedel”de ana karakter Kazangap veya Yedigey gibi gözükse de aslında Aytmatov, Kuttubayev gibi insanların mücadelesinden bahsetmek ister. "Mankurt"luğu ve böyle olan insan topluluklarını tenkit eder. "Mankurt" kelimesi Cengiz Aytmatov'un edebiyatımıza kazandırdığı, "köleleşmiş insan" anlamına gelen bir kelimedir.

Türkiye Türkçesi’ne birçok hikâye ve romanı kazandırılmış olan yazarımızın "Gün Olur Asra Bedel" isimli romanı, ilk olarak Rusça yayımlanmıştır. Daha sonraları 1985 tarihinde Cem Yayınları'ndan ve 1991 tarihinde Ötüken Yayınları'ndan çıkan baskılar ile Türkiye Türkçesi'ne kazandırılmıştır. Eserin çalışmamızda yararlandığımız Ötüken Neşriyat tarafından hazırlanan 58. baskısında 12 Bölüm bulunmaktadır ve eser 413 sayfadan müteşekkildir.

\section{Gün Olur Asra Bedel'de olay örgüsü (hâldeki olaylar)}

İngiliz araştırmacı ve yazar E. M. Forster (2014), olay örgüsünün; olayların zaman sırasına göre neden-sonuç ilişkisi içinde anlatılması olduğunu söyler. Öykü, olayların zaman sırasına göre nakledilmesi iken olay örgüsünde işin içine neden-sonuç girer. Bir romanda olay örgüsü iyi bir şekilde verilebilmişse, romanın sonunda okuyucuya verdiği sanatsal zevk farklı olacaktır (s. 128).

Romanda vaka, öykü neden-sonuç ilişkisine sokularak bize verilir. Olay örgüsünü oluşturan şey de aslında metin halkaları dediğimiz unsurdur. Ama olay örgüsü metin halkalarının üstünde bir yapıdır. $\mathrm{Bu}$ yüzden olay örgüsü, romanın kurgusu için çok önemli bir unsurdur. Romandaki her türlü unsuru kapsayan bir yapıdır. 
Mehmet Tekin (2019)'e göre olay örgüsü; romanın sesidir. Bu ses kimi zaman fisıltı, kimi zaman çı̆̆lı şeklindedir. Bu ses romanın sonuna kadar devam eder (s. 74). Romanı roman yapan onun kendine has olan planıdır. Roman bu yönüyle de gerçek hayattan ayrılır.

Romanda olay örgüsü ve kurgu, çok sağlam olmalıdır ki tüm unsurlar sağlam olsun. Okurun romana duyacağı ilgi, bir sonraki olacak şeye karşı duyduğu merak; bunların hepsi olay örgüsünün özenle örülmüş olmasıyla alakalıdır. Olay örgüsü bu bağlamda hata kabul etmeyen, yüksek düşünce kabiliyeti isteyen bir yapıdır. Nihayetinde bir romana estetik mahiyet katan en önemli unsur biçim olduğundan ve biçim de olay örgüsüne bağlı olduğundan, olay örgüsü başlıca yapı taşlarındandır.

Romanda karakterlerin iyi kurgulanması bile olay örgüsünün doğru işlemesinden doğar. Çünkü her unsur gibi karakterler de olay örgüsünün içinde kendilerine yer bulurlar. Romanın sonunda karakterlerin başına gelenler yahut olayların nihayete erme şekli okuyucunun hoşuna gitmeyebilir. $\mathrm{Bu}$ olay örgüsünün önünde sonunda bir sonuca bağlanması özelliğinin doğal neticesidir. Bize karmaşık gelen, sırrını roman boyunca çözmeye çalıştığımız bir olay örgüsü, aslında romanın sonunda birden çözülüp açık bir hâle gelir çoğu zaman.

Bir roman okuyucusu; olayın yapısına, gidişatına, sebep-sonuç ilişkilerinin kurgulanışına dikkat etmelidir. Çünkü yazar bunları belli bir gayeye göre düzenler. Bu bizi olay örgüsüne götürür. Görülüyor ki her kapı, olay örgüsünün romandaki temel yapı unsuru olmasına çıkmaktadır.

Romanlarda olay örgüsü karşımıza üç şekilde çıkabilir. Öncelikle eserde olay örgüsü, kronolojik olarak ilerleyebilir. Yani olaylar tarihi düzen içindeki sırasına göre sürüp gider ve son bulur. İkinci tip olay örgüsü ise; çerçeve olay örgüsüdür. Bu tip olay örgüsünde küçük boyutlu olaylar zümresini kapsayan bir ana olay bulunur. Üçüncü tip olay örgüsü ise; birbirinden farklı seyreden iki olay halkasının bir yerde birleşip tekrar ayrılması ile oluşur.

"Gün Olur Asra Bedel" romanında, iki veya daha fazla olay zincirinin kesişmesi, sonra ayrılmaları görülür. Romanın ana kahramanı Yedigey'in çevresinde gerçekleşen olaylar ile Parite Uzay İstasyonu'nun etrafında gelişen olaylar ayrı ayrı devam eder. Nadiren ise birleşir ve ayrılırlar.

"Gün Olur Asra Bedel" romanının kurgusunda olaylar üç katmanda gerçekleşmektedir. Bunları şu şekilde sıralayabiliriz:

\section{Olay Zamanı (vaka zamanı)}

2. Uzak Geçmiş Zaman

\section{Gelecek}

Olay zamanı (vaka zamanı), romandaki esas zamandır. Uzak geçmiş zaman, romanda geriye dönüşlerle verilen, çeşitli efsanelerin verildiği zamandır. Gelecek zaman katmanı ise uzay zamanı saati ile ölçülen zamandır.

Roman metninin başladığg yer, illaki olay örgüsünün başladığı yer olmak zorunda değildir. Olayın başladığı yer romanın ilerleyen sayfalarında da karşımıza çıkabilir. Fakat bizim incelediğimiz "Gün Olur Asra Bedel" romanında, olay zamanı ile metin beraber başlamaktadır. Arka planda ise çok daha geniş bir sosyal zaman verilecektir.

"Gün Olur Asa Bedel" romanında; asıl zamanda gerçekleşen yani hâldeki olaylar, Ukubala'nın (Yedigey'in karısı) Yedigey’e, arkadaşı Kazangap'ın ölüm haberini getirişi ile başlar ve Kazangap'ın cenazesinin gömülmesine kadar devam eder. Yani romanı başlatan ve sonra sonuna kadar devam eden, hâlde gerçekleşen olaylar bu süreci kapsar.

Arka planda verilen bütün olaylar, romancının geriye dönüş tekniğiyle yahut başka tekniklerle Yedigey'e hatırlattığı olaylardır. Yedigey' in, ailesinin, dostu Kazangap'ın ve bir diğer dostu Abu Talip'in geçmişi bu şekilde verilir. Bu geçmiş yine türlü türlü sosyal hadiseleri içine alır. Yazarımız Aytmatov, tüm romana hâkim olan o dev tema "mankurtluk"u da bu şekilde "Ana Beyit" Mezarlığı Efsanesi ile verir. 
Demir, S. (2021). "Gün Olur Asra Bedel" romaninda hâldeki olaylarm olay örgüsüne nakş̧ediliş̧i ve romanda anlatım tekniklerinin kullanilişı.

Kimi araştırmacıya göre hâldeki olaylar 24 saatlik bir zaman dilimini oluştururken, kimi araştırmacılar bu zaman diliminin üç gün olduğunu düşünmektedir. Tam da bundandır ki, romana ilk verilen adı "Obruç" sansüre uğrayınca, roman "Gün Uzar Yüzyıl Olur" ismini alır. Yani aslında kısa bir zaman diliminden bahsedilirken, roman boyunca geçmişe gidilip gelinerek zaman uzar da uzar. Bizim kanaatimize göre, hâldeki olaylar üç günlük bir zaman dilimini kapsar. Zira, Kazangap öldükten sonra, Yedigey onu yıkıyor, hazırlıklar başlıyor, ertesi gün defin için yola çıkılıyor. Romanda bu kısmın nasıl geçtiğini, romandan örnekler verdiğimiz ilerleyen sayfalarda göreceğiz.

Biz romandaki olay zamanında gerçekleşenleri yani hâldeki olayları romandan örnekler vererek incelemeye çalışacağız:

Romanın birinci bölümü, aç tilkinin yemek arayışı ile başlar yani roman hâldeki olaylar ile başlar: "Aç tilki, av araya araya demir yoluna yaklaşmıştı. Bozkır boyunca, koyu, düz bir şerit gibi uzanan demir yolu onu hem korkutuyor hem de kendine çekiyordu" (Aytmatov, 2018, s. 7). Romanda tilki doğayı temsilen bulunur ve insanların doğaya olan zararı tilki nezdinde verilmeye çalışılır. Yani olay örgüsünde tilkinin varlığı sebepsiz değildir. Tilki hâldeki olaylarda önemli bir noktadır.

Romanın birinci bölümünün devamında, Ukubala, eşi Yedigey’e Kazangap'ın ölüm haberini getirir. Bu da hâldeki olaylarda önemli bir yer teşkil eder. Olaylara giriş bu şekilde başlar:

"İçeriye girdiler ve Yedigey karısına:

- Otur, biraz soluk al, dedi.

- Sen de otur.

Oturdular.

- Ne oldu? Ne var?

- Kazangap öldü” (Aytmatov, 2018, s. 12).

Bu kısımda, Ukubala haberi vermek için koşarken, yazar, Yedigey’in kendi iç düşüncelerine de yer vererek Ukubala'yı bize tanıtır. Onun ne kadar yaşlandığından bahseder. İstasyon halkına haberin verilmesi, yarınki cenaze töreni için Yedigey'in hemen hazırlıklara başlaması gibi olaylar silsilesi bu şekilde devam eder. Emektar deve Karanar'1 hazırlarken Yedigey, dostu Kazangap ile olan mâzisini hatırlar. Olay örgüsünün bu kısmında hâldeki olaylar kesilir, geriye dönüş başlar.

Romanın ikinci bölümünde, Yedigey’in, cenazeyi Ana Beyit mezarlığına gömmek için istasyon halkını ikna etmeye çalışması, olay örgüsünün hâldeki olaylar merhalesi için oldukça önemli yer kaplar. Bu kısımda Ana Beyit'in önemi ve kültürümüzdeki yeri verilmeye çalışılır: “- Bırakın bu boş lafları, ne biçim yiğitlersiniz siz! Böyle bir adamı atalarının yattığı yer olan Ana Beyit'ten başka bir yere gömemeyiz. Zaten kendisi de bunu istemiş̧ti” (Aytmatov, 2018, s. 31).

Cengiz Aytmatov'un babası rejim tarafindan katledildikten sonra, Kırgızistan Bişkek’teki Ata Beyit mezarlığına defnedilmiştir. Romanda da buna benzer olarak Ana Beyit mezarlığı vardır. Aytmatov için babası ve nice aydının katledilip gömüldüğü Ata Beyit ne ise, Kazak halkı, bilhassa da Boranlı Yedigey için Ana Beyit odur.

Yediyeg'in jeolog arkadaşı Yelizarov da hâldeki olaylarda önemli bir yer tutar. Romanda Yelizarov vasitasıyla, Aytmatov, Juan-juanlar'ın yaptıkları istilaları verir. Yelizarov, Boranlı İstasyonu halkına kendi geçmişleriyle alakalı tarihi malzeme sunmuş olur.

Romanın birçok yerinde vurgulanan gelenekler ve bunların doğru uygulanmasının önemi, Yedigey'in cenazeyi gömme hazırlıklarında da karşımıza çıkar. Yedigey cenazenin âdetlere uygun bir şekilde yıkanması gerektiğini savunur. Arkadaşı Kazangap'ı kendi başına yıkar: "Âdetlere göre bu iş, ölünün gömüleceği gün cenaze namazı kılınmadan önce yapılırdı. Ama sabahleyin erkenden yola koyulacakları için Yedigey bu işi geceleyin yapmıştı. Hemen hemen tek başına yapmıştı bu işi” (Aytmatov, 2018, s. 69). 
Hâldeki olaylarda değinmemiz gereken bir başka nokta ise Karanar'dır. Karanar, Kazangap'ın Yedigey'e, hoş geldin hediyesi olarak verdiği, ilerleyen zamanlarda Yedigey için hem bir binek hem bir dost olacak Akbaş'in yavrusu olan devedir.

Romanın ilerleyen bölümlerinde, hâldeki olayları, Yedigey ve ahâlinin cenazeyi gömmek için Ana Beyit'e olan yolculuğu oluşturur. Hâlde gerçekleşen olayların önemli noktalarından bir diğeri ise, askerlerin Ana Beyit'i kapatması ve cenazenin oraya gömülmesine izin vermemesidir: "Bu mezarlık yakında tamamen kaldırılacak, yok olacak! Buraya yeni bir yerleşim birimi kuracaklar" (Aytmatov, 2018, s. 388).

Olay; Yedigey'in cenazeyi Ana Beyit'e gömemese bile, Kazangap'ın vasiyetini yerine getirmek istediği ve âdetlere göre cenazeyi gömmeden geri götürmek doğru olmadığ 1 için, cenazeyi orada Malakumdıçap vadisine gömme kararı ile son bulur: "- Törelerimize karşı çıkmayın. Tabiat kanunlarına da karşı çıkmayın! Mezara götürülen bir ölü asla geri getirilemez. Cenazeyi burada gömecek, töreni burada yapacağız" (Aytmatov, 2018, s. 393). Yedigey defin işleminden sonra, Allah'a dua eder. Tek dileği, öldükten sonra bu topraklara, Kazangap'ın yanına gömülmektir. Yedigey, hüngür hüngür ağlayarak, bu topraklarda türlü anılar biriktirdiği dostu Kazangap ile vedalaşır.

\section{Gün Olur Asra Bedel' de Anlatım Tekniklerinin Kullanılışı}

Roman, hikâye, deneme vs. her edebî tür bir anlatıdır. Yazarlar eserlerini kaleme alırken, olayları olay örgüsüne oturturken bazı anlatım tekniklerinden yararlanırlar. Bu anlatım teknikleri sayesinde bazen olaylar açıklığa kavuşur, bazen kahramanların özellikleri verilir, bazen geçmişte yaşanan bir olay okuyucuya anlatılır.

Biz, yazarımız Cengiz Aytmatov'un "Gün Olur Asra Bedel” eserini kaleme alırken kullandığı anlatım tekniklerinden, örnekler yoluyla bunları ne amaçla kullandığından bahsedeceğiz.

Çalışmamız, eserin 86-112 sayfaları arasında kullanılan anlatım teknikleri ile sınırlıdır. Biz burada, söz konusu sayfa aralığında yazarın hangi anlatım tekniklerini kaç kez kullandığını tespit etmeye ve bunlara örnekler verip açıklamaya çalışacağız. Yazarın bu sayfalar arasında yıldızlarla ayırdığı dört kısım vardır. Fakat ilk kısım ve son kısmın belli bir parçası, inceleyeceğimiz sayfa aralığının dışında kalmaktadır. Anlatım tekniklerini tespit ederken ilgili sayfa aralığını paragraf okuyup inceledik. Her roman bir anlatı olduğu ve neredeyse romanın tamamı "anlatma-gösterme tekniği" temelinde kaleme alındığ1 için, "geriye dönüş" tekniğinin kullanıldığı metin parçalarındaki anlatma ve gösterme tekniklerini tespit etsek de bunları "Anlatma-Gösterme Tekniğiı" başlığı altında hesaplamamayı uygun gördük. Böylece çalışmamızda sayıları hesaplanan anlatma ve gösterme teknikleri, geriye dönüş parçalarının haricinde bulunanlardır.

\subsection{Anlatma-gösterme teknikleri}

Romancı hikâyesini anlatırken, okuyucuya birtakım tuzaklar kurar: Kaliteli romancı, kurduğu tuzakların gerisinde durup okuyucusuyla saklambaç oynayan, onunla yerine göre dalga geçen, nihayet okuyucusuyla birlikte eğlenen, gülen, yalan söyleyen, sır tutan, yerine göre sırrı açıklayan... romancıdır. Bütün bu eylemlerin maskesi ise, "anlatma" ve "gösterme"dir (Tekin, 2019, s. 208).

\subsubsection{Anlatma}

Destan devrinde, hikâyeyi anlatan ve ön planda olan hep anlatıcıydı. Hikâye okuyucuya, anlatıcının süzgecinden geçerek veriliyordu. Bugüne geldiğimizde bunu diğer edebî eserlerde de görürüz. Romanlarda da anlatıcıların ve anlatma faktörünün yeri büyüktür. Modern edebiyatta bir teknik olarak kullanılan anlatma, genellikle karşımıza yazar anlatıcı olarak çıkar. Metinde dikkat en fazla anlatıcı üzerine toplanmışsa o metin, "anlatma" tekniğinin yoğun olarak kullanıldığı bir metindir (Tekin, 2019, ss. 199-200).

“Gün Olur Asra Bedel” romanında, 86-112 sayfalar arasında yıldızlarla ayrılmış kısımlarda 17 tane anlatma tekniği kullanılmıştır. 
Demir, S. (2021). "Gün Olur Asra Bedel" romaninda hâldeki olaylarm olay örgüsüne nakşedilişi ve romanda anlatım tekniklerinin kullanılişı.

"Kazangap işte böyle bir adamdı. Artık onun gibileri yoktu dünyada. Kazangap sonuncusuydu ve şimdi onu da gömeceklerdi" (Aytmatov, 2018, s. 108). Örnekte görüldüğü gibi olayların verilmesinde anlatıcı faktörü vardır. Kazangap'ın nasıl bir adam olduğunu okuyucuya anlatıcı bizzat anlatır. Kazangap'ın anlaşılması için yazar ve okuyucu arasına başka bir olay sokulmaz. Aşağıdaki örneklerde de bu tekniği açıkça görürüz:

“...Bu Boranlı macerasının nasıl sonuçlanacağını, burada ne kadar kalabileceklerini, kök salıp salamayacaklarını, başka yere göç edip etmeyeceklerini, Kazangap'ın onları getirdiği bu yerde koca bir ömür geçireceklerini de bilemezlerdi” (Aytmatov, 2018, s. 88).

"Yedigey bölgeyi iyi bilirdi. Hem Karanar'ın sırtında olduğu için çevresini ta uzaklara kadar görebiliyor, Ana Beyit'e en kestirme yolu seçiyordu. Arada bir kestirme yoldan biraz açılmasının sebebi, arkadan gelen araçları bir çukura düşmeden kolayca geçecekleri düzlüğe çekmek istemesiydi" (Aytmatov, 2018, s. 109).

"İnsanlık tarihinde o güne kadar görülmemiş bir keşfin yapıldığını onlardan başka hiç kimse bilmiyordu yeryüzünde" (Aytmatov, 2018, s. 110).

Örneklerde de görüldüğü gibi, yazar-okuyucu ilişkisi adeta perdesizdir. Okuyucu, yazar ile direkt temas halindedir. Olayların ve karakterlerin nasıl anlaşılacağı yazarın tasarrufundadır.

\subsubsection{Gösterme}

Metinlerde "anlatma" tekniğinin yoğun olarak kullanılması ve ilginin metinden çok anlatıcıya kayması üzerine realistler, bu tekniğin yetersiz olduğunu düşünmüşlerdir. "Anlatma" tekniği ile okuyucuyu eserin dünyasına sokmak oldukça güçtür. Bu yetersizliği gidermek için, "gösterme" tekniğini ortaya çıkarmışlardır. Bu anlamda yazarlar bir görsel sanat olan tiyatrodan yararlanmışlardır. $\mathrm{Bu}$ şekilde dikkat, tekrar metne çevrilmiştir ve bu teknik roman sanatına bir gelişme katmıştır (Tekin, 2019, ss. 200-202).

“Gün Olur Asra Bedel” romanında, 86-112 sayfalar arasında yıldızlarla ayrılmış kısımlarda 12 tane gösterme tekniği kullanılmıştır.

"Tren trene ekleniyor, makas açılsın, yeşil ışık yansın diye lokomotifler keskin düdüklerini öttürüyor, aynı şekilde karşı yönden gelen trenler de sirenlerini çı̆̆lık gibi öttürmekte onlardan geri kalmıyordu" (Aytmatov, 2018, s. 89). Gösterme tekniğinin kullanıldığı bu parçada, görüldüğü gibi hep bir aksiyon vardır. Trenlerin birbirini takip etmesi, makasların açılıp kapanması, lokomotif düdüklerinin ötmesi vb. hiçbir şey durağan değildir.

“Önden giden Kazangap durup arkasına baktı. Deve sırtında giden Yedigey’e ve onun yanında yürüyen Ukubala'ya eliyle ilerisini göstererek: - İşte bizim Boranlı, dedi. Az bir yol kaldı, varınca dinlenirsiniz" (Aytmatov, 2018, ss. 92-93). Örnekte görüldügü gibi yazar burada da gösterme tekniğini kullanmıştır. Metinde eylem söz konusudur ve olay, gösterme tekniği yardımı ile okuyucunun gözünde canlandırılmaya çalışılmıştır. Anlatıcı adeta aradan çekilmiş, okuyucu kahramanlarla baş başa bırakilmıştır.

“Sabah erkenden her şey hazırdı. Kazangap'ın naaşı bir keçeye sımsıkı sarılmış, yün iplerle bağlanmış ve bir traktörün römorkuna yerleştirilmişti. Naaşın konduğu yere önceden biraz talaş, yonga ve bir kat temiz ot sermişlerdi" (Aytmatov, 2018, s. 100). Burada da Kazangap'ın naaşının gömülmeye nasıl hazırlandığı, gösterme tekniği yardımıyla okuyucunun gözünde canlandırılmaya çalışılmıştır.

Gösterme tekniğine bir başka örnek de şöyledir: "En küçüğünden en büyüğüne kadar bütün Boranlılar orada, cenazeyi taşıyan römorkun hareket etmesini bekliyordu. Kadınlar durmadan ağliyorlardı" (Aytmatov, 2018, s. 101).

\subsubsection{Anlatma-gösterme iç içe}

"Anlatma" ve "gösterme" tekniklerinin iç içe kullanılması anlatıyı güçlendiren bir unsurdur. Realistlerden sonra romancilar eserlerinde bu iç içe tekniği çokça kullanıp güçlü eserler kaleme 
almışlardır. Örneğin; Oya Baydar, "Hiçbiryer'e Dönüş" isimli romanında, Peyami Safa ise "Yalnızız" romanında bu tekniği kullanmıştır (Tekin, 2019, s. 206).

“Gün Olur Asra Bedel” romanında, 86-112 sayfalar arasında yıldızlarla ayrılmış kısımlarda 10 tane, anlatma-gösterme tekniğinin iç içe kullanıldığı örnek bulunmaktadır. İç içe kullanılan bu teknik genellikle karşımıza bir paragrafta birbirinin devamı cümleler şeklinde çıkar. Vereceğimiz örneklerde "normal" yazı stiliyle yazılanlar anlatma, "italik" yazı stiliyle yazılanlar ise gösterme cümleleridir.

"Kış gelince küçük Karanar epeyce büyümüştü. Ona, üşümesin diye, karnının altından açıllp kapanan bir örtü diktiler" (Aytmatov, 2018, s. 94).

"Yedigey'in böyle bir niyeti olmadığı hâlde, bu konuşması küçük bir cenaze töreni olmuştu. Bundan sonra yola koyuldular. Boranlılar cenaze arabasının ardından bir süre yürüdüler, sonra, köyün çıkışında, topluca durdular" (Aytmatov, 2018, s.102). Görüldüğü gibi, anlatma tekniğinin kullanıldığ1 kısımlarda bir durum tespiti; gösterme tekniğinin kullanıldığ 1 metin parçalarında ise bir aksiyon, bir hareket vardır.

\subsection{Tasvir}

"Tasvir", "sûret" kelimesinden türemiş ve "resmini yapma, figür, portre" anlamlarına gelmektedir. Yani, “yazıyla tarif etme sanatı”dır (Develioğlu, 2015, s. 1212).

Çetişli (2019), tasviri, kurmaca bir eserdeki zaman, mekân, olay vb. unsurların daha anlaşılır hâle getirilmesi için kullanılan, anlatılmak isteneni somut hâle getiren bir teknik olarak değerlendirir (s. 100). Temel özelliğiyle anlatma, bir şeyi somutlaştırmaktır. Romanda bunu en iyi uygulamanın yollarından biri de işte bu "tasvir" tekniğidir. Tasvir etmek esasen bir olayı veya durumu olduğu hâliyle vermek değildir. Romancı anlattığını sanki gerçekmiş gibi vermeye çalışır. Bunu da ayrıntıları yakalamaya çalışarak, karakterleri çok iyi gözlemleyerek yapar. Romantikler, realistler ve ardından natüralistler, tasvir yöntemini geliştirerek eserlerinde kullanmışlardır (Tekin, 2019, ss. 209-210).

"Gün Olur Asra Bedel" romanında, 86-112 sayfalar arasında yıldızlarla ayrılmış kısımlarda 9 tane tasvir (betimleme) tekniği kullanılmıştır. Biz bu tasvirleri içeriklerine göre; mekân, insan, hayvan olarak sinıflandırmayı uygun gördük. Tespit ettiğimiz tasvirlerden 5 tanesi mekân, 1 tanesi insan, 3 tanesi hayvan tasviridir.

Mekân tasvirine örnekler: "Önce hafif hafif esti rüzgâr, sonra gittikçe hızını arttırarak sessizliği bozdu, uğul uğul, karları savuran bir bora oldu ve nihâyet kar firtınasına dönüştü” (Aytmatov, 2018, ss. 89-90).

"Bozkırın ortasında oyuncak trenler gibi görünüyordu o uzun uzun katarlar. Batmakta olan güneş, çevredeki tepeleri ve vadileri gölge-1ş1k oyunlarıyla belli ediyor, alaca karanlık gittikçe koyulaşıyordu. Kış nemini hâlâ yitirmemiş toprakta serince bir bahar kokusu vardı" (Aytmatov, 2018, s. 92).

"Az sonra güneş batmış, karanlık çökmüştü. Sarı-Özek göğünde sayısız yıldızlar 1şıldamaya başlamış, onlar da Boranlı'ya gelip durmuşlardı" (Aytmatov, 2018, s. 93). Örneklerde görüldügü gibi yazar olayın meydâna geldiği mekânı tasvir ederken, okuyucuyu adeta o ortamdaymış gibi hissettiriyor. Esen rüzgârı, okuyucu da saçlarında hissediyor.

İnsan tasvirine örnek: "Sinekkaydı tıraş olmuş, bıyıklarını düzeltmiş, önemli günler için ayırdığı en güzel elbisesini giymişti: Siyah ceket, beyaz gömlek, kadife şalvar ve ayaklarında meşin çizmeler, başında demiryolcu şapkası" (Aytmatov, 2018, ss. 100-101).

Hayvan tasvirine örnekler: "Akbaş'ın yavrusu henüz bir buçuk hafta önce doğmuştu. Kara başl1, iki küçücük kara hörgüçlü bir köşek idi” (Aytmatov, 2018, s. 94).

"Uzun, kalın damarlı ve yorulmak bilmeyen bacakları ise, ölçülü adımlarla havayı yarıp ilerliyordu" (Aytmatov, 2018, s. 103). Görüldüğü gibi yazar, meşhur deve Karanar'ın, ne denli güçlü bir deve olduğunu okuyucunun zihninde canlandırabilmek için tasvir tekniğini birden fazla kez kullanmıştır. 
Demir, S. (2021). "Gün Olur Asra Bedel" romaninda hâldeki olaylarm olay örgüsüne nakşedilişi ve romanda anlatım tekniklerinin kullanılışı.

Sözünü ettiğimiz "Gün Olur Asra Bedel" ve daha birçok romanda, tasvir tekniği romanın güçlü unsurlarından olmuştur. Çünkü okurun ilgisini çekebilecek detaylar, bu teknikle çokça verilmektedir.

\subsection{Mektup tekniği}

Bildiğimiz gibi mektup, bir anlatım tekniği olmasının yanında aynı zamanda bir edebî türdür. Teknolojinin bu denli gelişmesinden önce mektup, yıllarca özel yâhut resmi konular için, bir yazışma aracı olmuştur. Mektubun yaygın bir tür olarak kullanımı 17. yüzyılda başlamıştır. Diğer türlere göre daha özel ve öznel ifadelerin yer aldığı metinlerdir. Bu görevinin yanında mektup, edebî eserlerde de bir teknik olarak 18. yüzyıldan itibaren kendini göstermiştir (Tekin, 2019, ss. 235-236). Romanlarda âşıkların hislerini dile getirmek için mektuplaştıklarını ya da bir kimsenin başka bir kimse ile haberleşmek için mektup yazdığını sık sık görürüz.

Mektup tekniği, romanlarda genellikle karşımıza iki türlü çıkar. Birinci tür; yazarın romanını, sadece mektuplaşmalardan meydana getirmesidir. Örneğin, ünlü bir Türk edebiyatı yazarı olan Halide Edip, "Handan"1 mektuplaşmalardan oluşturmuştur. Mektup tekniğinin romanlarda bir diğer kullanımı ise, gerekli görülen yerlerde parçalar halinde kullanılmasıdır. Tekniğin bu şekilde kullanımı oldukça yaygındır (Tekin, 2019, s. 238).

"Gün Olur Asra Bedel" romanında, 86-112 sayfalar arasında yıldızlarla ayrılmış kısımlarda 1 tane mektup tekniği kullanılmıştır. Bizim inceleyeceğimiz sayfa aralığı 112'de bittiği ve söz konusu mektup örneği ise 111-121 sayfaları arasını kapsadığı için, biz sadece inceleyeceğimiz sayfa aralığından örnek vereceğiz.

\section{"Dikkat! Dikkat!}

$\mathrm{Bu}$ yıldızlar arası yayın dünya içindir!

Dünyalıların dilinde adları bile olmayan şeyleri anlatmak çok zor, yine de bizim gezegenimizle birçok ortak nokta bulunmaktadır. Orman gezegenliler insana benzeyen yaratıklar, aslında bizim gibi insanlardır. Yaşasın dünya evrimi”" (Aytmatov, 2018, s. 111).

Yazarın mektup tekniğini kullandığı kısımda, Orman-Göğsü gezegenine giden iki kozmonot dünyalılara oradan bir mesaj bir nevi mektup göndermişleridir. Bu mektupta o gezegendeki canlıların ne mahiyete sahip olduklarından bahsedilir. Kozmonotlar, Orman-Göğsü gezegenindeki varlıkların aynı insanlara benzediğini şaşkınlıkla mektupta anlatırlar.

\section{4. Özetleme tekniği}

Özetleme tekniği genellikle, uzun uzadıya verilmek istenmeyen bir dizi olayı veya durumu kısaca vermek adı üzerinde özetlemek için kullanılır. Bu da metne daha derli toplu bir boyut kazandırır. Böylece tüm ayrıntısıyla anlatılsa, sayfalar boyu sürecek detaylar daha öz şekilde verilmiş olur. Bu da okuyucu açısından metni akıcı kılan bir unsur olur (Tekin, 2019, s. 241).

Söylenmelidir ki, bir edebî eserdeki her şey aynı ölçüde detaylandırılırsa, romanın özü açısından daha önemli olan metin parçaları, yeterince dikkat çekmez. Bundan dolayı özetleme tekniği roman için elzem bir tekniktir.

"Gün Olur Asra Bedel" romanında, 86-112 sayfalar arasında yıldızlarla ayrılmış kısımlarda 3 tane özetleme tekniği kullanılmıştır.

“Artık çocukları olmuş, büyümüş, Boranlı’ya kök salmışlardı" (Aytmatov, 2018, s. 87). Bu cümlede görüldüğü gibi, Yedigey ve Ukubala'nın çocuklarının oluşu, büyümeleri ve Boranlı' ya iyice alışıp burada bir süredir yaşama süreçleri detaylı verilmeyip özetlenerek verilmiştir.

"Yedigey, Karanar'ı iğdiş etmedi. Daha doğrusu gönlü razı olmadı, eli varmadı. Onu atan (damızlık) olarak bıraktı. Ama öyle zamanlar oldu ki Karanar ona kan kusturdu" (Aytmatov, 2018, s. 99). Bu örnekte de görüldüğü gibi Yedigey'in Karanar'ı iğdiş etmeyip bunun sonucunda hayvanın ona sıkıntı çektirmesi son cümle ile özetlenmiştir. 
Yedigey ve Ukubala'nın, Boranlı'ya gelince ilk başta kaldıkları yerler şu örnekte olduğu gibi özetleme tekniği ile verilmiştir: "Birkaç gün Kazangap'ın evinde kaldılar. Sonra, yol işçilerinin kaldığ1 barakada onlara da bir oda verildi ve oraya taşındılar. Boranlı'daki hayatları böyle başladı" (Aytmatov, 2018, s. 93).

$\mathrm{Bu}$ örneklerde anlatılan olaylar elbette ki romanın seyri için önemlidir. Fakat özetleme tekniğiyle olayın veya durumun özünün verilmesi romanı daha anlaşılır ve akıcı kılmıştır. Böylece kısaca açıklanarak da yeterince anlaşılacak bazı olaylar, okuyucunun aklını çok uzun süre meşgul etmeyecek, okuma akışını bozmayacaktır. Belki de ayları, hatta yılları alan olaylar, bir çırpıda bilinmiş olacaktır.

\subsection{Geriye dönüs tekniği}

Romanlarda olaylar şimdiki zamanın içinde kurgulansa da romanı roman yapan bir tek içinde bulunulan zaman değildir. Yazar içinde bulunulan zamandan, geçmişe dönerek yaşananlara açıklık kazandırır. Geriye dönüş tekniği, eserlerde çoğu zaman, okuyucunun daha önceden yaşanan bir olayı öğrenmesi, böylece olayların alt zeminine hâkim olması için yahut kahramanların hayat hikâyelerinin verilmesi için kullanılır. Çünkü, okuyucunun merak duygusunu kamçılamak için, karakterler genelde en baştan anlatılmaz. Geriye dönüşlerle karakter olayın içine katılır (Tekin, 2019, ss. 244-245). Filmlerde "flashback" adlandırılan bu uygulama, roman sanatı için çok elzem bir unsurdur.

“Gün Olur Asra Bedel” romanında, 86-112 sayfalar arasında yıldızlarla ayrılmış kısımlarda 5 tane geriye dönüş tekniği kullanılmıştır.

Kazangap, Sarı-Özek'e yerleşeli çok olsa da geçmişi hiç unutamıyordu. Özellikle iki tatsız anı, sürekli aklına geliyordu. Yazar bu iki tatsız anıyı, bize geriye dönüş ile anlatmıştır.

“Sabitcan'ın köye geldiği günlerden birinde, oturmuş, çay içiyor, sohbet ediyor, şehirde olup bitenleri dinliyorlardı ondan. Söz arasında Sabitcan gülerek, kollektifleştirme devrinde Sincan'a (Doğu Türkistan'a) kaçan Kazak ve Kırgızlar'ın geri gelmeye başladıklarından söz etti” (Aytmatov, 2018, s. 86). Burada görüldüğü gibi yazar, Sabitcan'ın köye geldiği günlerden birinde yaşanan olayı babası Kazangap'ın hatırlaması yoluyla anlatmış, ardından, Kazangap'ın oğluna sinirlenip ortamdan ayrılmasıyla bu tatsız anıyı anlatmayı bitirmiş, geriye dönüş de şu şekilde son bulmuştur: "Kazangap böyle dedikten sonra suratını astı, kimsenin yüzüne bakmadan çıkıp gitti” (Aytmatov, 2018, s. 87).

Kazangap'ın anımsadığı ikinci tatsız olay da Yedigey ile arasında geçen ufak tartışmadır. Yazar bu olayı da yine geriye dönüş tekniği ile okuyucuya aktarmıştır:

Bir bahar akşamıydı. Sürüleri ağıla kapatmış, koyun-kuzuların arttığını görüp memnun olmuşlardı. Yedigey şaka olsun diye Kazangap'a:

-Ee, Kazake, sen ve ben zengin insanlar, kulaklar olduk. Yakında bir kere daha malımızı mülkümüzü alıp bizi sürmesinler sakın! dedi.

-Kazangap, Yedigey'e sert sert baktı, bıyıkları da diken diken oldu:

-Sözüne dikkat et Yedigey! dedi...

-Şaka yaptım Kazake, şakadan anlamaz mısın?

-Bazı şeyler vardır ki onlarla şaka yapılmaz! (Aytmatov, 2018, s. 87)

Romandaki bir diğer geriye dönüş ise, Yedigey'in devesi Karanar ile yaşadığı bir hatırayı anlatmak için yapılmıştır. "Yedigey şu olayı da hatırlıyordu: Aradan uzun yıllar geçip Boranlı Karanar yörede ün kazanınca, bir gün, Sarı Özek'e sırf onun fotoğrafını çekmek için insanlar geldi” (Aytmatov, 2018, s. 95). Bu anı tamamlanıp geriye dönüş bittiğinde, yazar Kazangap'ın defni için yapılan hazırlıkları anlatmaya devam etmiştir.

"Bir keresinde, kardan tıkanan yolları açmak için durup dinlenmeden tam kırk sekiz saat çalışmış, geceleyin önlerini bir lokomotifin farlarıyla aydınlatmışlardı" (Aytmatov, 2018, s. 106). Bu cümlede olduğu gibi yazar, "bir keresinde" şeklinde başlayıp geçmişte yaşanan bir olayı, Kazangap ile 
Demir, S. (2021). "Gün Olur Asra Bedel" romaninda hâldeki olaylarm olay örgüsüne nakş̧edilişi ve romanda anlatım tekniklerinin kullanılişı.

Yedigey'in kar altında çalışırken ettikleri kavgayı okuyucuya anlatııs, ardından "Yaa, işte böyle, kavga da etmişlerdi” (Aytmatov, 2018, s. 108) cümlesi ile geriye dönüşü bitirmiştir.

Romanın konusunu ettiğimiz sayfa aralığında yapılan son geriye dönüş ise, Yedigey'in şehirde karşılaştığı bir cenaze üzerine yaşadığı şaşkınlığı anlatmak için yapılmıştır. Sarı-Özek bozkırında yaşanan hayat ve gelenekler başka, şehirdeki hayat bambaşka gibidir. "Bir gün, şehirde bir cenaze törenine katılmış ve mezarlıktaki o törenin herhangi bir toplantıdan farksız geçtiğini görünce şaşırıp kalmıştı. Birtakım hatipler ellerindeki kâğıtlarla merhumun tabutu başına gelmiş, nutuk okumuşlardı" (Aytmatov, 2018, s. 109).

\subsection{Montaj tekniği}

Tekin (2019), montaj tekniğini, romancının, kültürel açıdan bir değer ifade eden bir metni, bir söz veya yazıyı, kalıp şeklinde eserde belli bir amaç üzere, kullanması şeklinde açıklar (s. 254). Yazar montaj tekniğini eserinde kullanırken, genel kültüre dair; türkü, efsane gibi bazı metin parçalarını eserine ekler. Bu tekniği kullanırken parçayı ya aynen ya da genel manasını verecek şekilde kullanır.

Aslına bakılırsa bu teknik, Türk edebiyatında önemli bir yeri olan "iktibâs" sanatına benzer. "Iktibâs" kelime olarak "ödünç alma", edebî metinlerde ise, "bir kelimeyi; bir cümleyi veya bunların mânâlarını olduğu gibi alma, aktarma" anlamına gelmektedir (Develioğlu, 2015, s. 488).

“Gün Olur Asra Bedel” romanında, 86-112 sayfalar arasında yıldızlarla ayrılmış kısımlarda 1 tane montaj tekniği kullanılmıştır.

"Efsaneye göre, Akmaya'nın yedi yavrusu olmuş: Dördü dişi, üçü erkek. O zamandan beri dişi develerin hepsi ak başlı, açık renkli, erkek develer ise kara başlı, kestane tüylü imiş" (Aytmatov, 2018, s. 99). Bu örnekte ve devamında, Akmaya Efsanesi montaj tekniği ile esere eklenmiştir. Efsane aynen alınmamış yazarın cümleleriyle açıklanmıştır. Montaj tekniğinin kullanıldığı bu metin parçasında, Karanar'ın soyunun nereden geldiği okuyucuya anlatılmıştır.

Montaj tekniği, romana tarihî ve kültürel derinlik katması açısından önem arz etmektedir. Cengiz Aytmatov, bunu romanında başarılı bir şekilde uygulamıştır. "Akmaya Efsanesi" romanı zenginleştiren bir unsurdur.

\subsection{Otobiyografik teknik}

Otobiyografi, “öz yaşam öyküsü” (Türk Dil Kurumu, t.y.) anlamına gelmektedir. Otobiyografi türünün en belirgin özelliği, kurmaca olmamasıdır. Otobiyografi, yazarın kendi yaşam öyküsünü, bizzat kendisinin anlatmasıdır. Bundan dolayıdır ki, otobiyografi yazarı tarafsız değildir. Çünkü anlattığı olay, kendi öz yaşamı olduğu için, elbette ki anlatıma kendi yorum ve hislerini katacaktır.

"Otobiyografi" ve "otobiyografik roman" arasında önemli bir fark vardır. Adı üzerinde otobiyografik roman, roman edebî türünde yazılmış bir eserdir. Yazar öz yaşam öyküsünü, roman olarak adlandırır (Özyer, 1993, ss. 73-76).

Kendi öz yaşamından bazı kesitleri, romana ve romandaki karakterlere aktarabilmek ve bunu romanın özünü bozmadan yapabilmek romancının ustalığının göstergesidir. Romancı için, kendi hayat birikimini, anılarını, belki de tecrübelerini, bir roman karakterine mâl etmek büyük başarıdır (Tekin, 2019, s. 259).

Biz burada, otobiyografinin bir anlatım tekniği olarak, roman türünde kullanılmasının üzerinde duracağız. "Gün Olur Asra Bedel" isimli eserinde Cengiz Aytmatov, roman boyunca, direkt olarak kendi hayat hikâyesini anlatmaz. Romandaki kahramanlar ve onların hikâyeleri farklıdır. Bu anlamda eser bir otobiyografi kitabı değildir. Fakat eserde kullanılan mekânlar, kahramanların içinde bulunduğu sosyal durum ve buhranları, Cengiz Aytmatov'un da hayatından izler taşır. Bu yüzden, bir otobiyografi kitabı olmasa da eserin otobiyografik yönünün olduğunu ve yazarın eserde otobiyografik tekniği de kullandığını söylemeliyiz. 
Eserdeki kahramanlar aynı Cengiz Aytmatov gibi Sovyetler döneminde yaşamaktadırlar. Eserdeki Abutalip karakteri, Aytmatov'un babası Törekul gibi rejime karşı olduğu iddiasıyla yargılanmaktadır. Zarife karakteri, Aytmatov'un annesi Nagima Hanım gibi eşi gittikten sonra çocuklarına kol kanat gerip onları kendi yetiştirmiştir. Aytmatov'un babası toplu mezar olan Ata-Beyit'e gömülmüştür. Eserde Kazangap'ın gömülmeye götürüldüğü, adını Nayman Ana Efsanesi’nden alan kutsal mezar ise Ana-Beyit'tir.

Eserde bu saydığımız gibi daha birçok, Cengiz Aytmatov'un hayatına benzer olabilecek örnekler vardır. Söylemeliyiz ki, Aytmatov eserlerini kurgularken kesinlikle kendi hayatından da yararlanmıştır. Bu yönüyle "Gün Olur Asra Bedel" romanında da otobiyografik teknik kullanılmıştır.

\subsection{Leit motiv tekniği}

Leit motivler, bazı romanlarda sık sık tekrarlanan, anlamın pekişmesini sağlayan ve kalıp ifadeler olarak karşımıza çıkan kelime veya söz gruplarıdır. Aynı zamanda; telaffuz, jest ve mimikler vs. de romanda leit motiv olarak kullanılabilir. Bu tekrarlar metne kuvvet kazandırırlar (Tekin, 2019, ss. 262-264).

“Gün Olur Asra Bedel” romanında, 86-112 sayfalar arasında yıldızlarla ayrılmış kısımlarda 1 tane leit motiv tekniği kullanılmıştır:

Bu yerlerde trenler doğudan batıya, batıdan doğuya gelir gider... gelir giderdi...

$\mathrm{Bu}$ yerlerde demiryolunun her iki yanında 1ssız, engin, sarı kumlu bozkırların özeği Sarı-Özek uzar giderdi...

Coğrafyada uzaklıklar nasıl Greenwich meridyeninden başlıyorsa, bu yerlerde de mesafeler demir yoluna göre hesaplanırdı.

Trenler ise doğudan batıya, batıdan doğuya gider gelir... gider gelirdi... (Aytmatov, 2018, s. 100)

Romanda sürekli tekrarlanan bu leit motiv, roman için bir sembol niteliğindedir ve alelade bir yerde kullanılmamıştır. Roman boyunca her bölümün başlangıcında tekrarlanır. Bu leit motiv, Boranlı halkının hayata bakış açısını anlatması açısından çok önemlidir. Aynı, mesafelerin meridyenlere göre hesaplanması gibi, Boranlı halkı da mesafeleri demiryoluna göre hesaplıyordu. Bu anlamda Cengiz Aytmatov, romanında "leit motiv" tekniğini çok başarılı kullanmıştır.

\subsection{Diyalog tekniğ i}

Diyalog, iki veya daha fazla kişinin konuşmasıdır. Edebî metinlerde de karşı1ıklı konuşmaların olduğu metin parçalarıdır (Tekin, 2019, ss. 265-266). Diyalog tekniği, anlatmaya bağlı metinlerde, daha çok roman gibi kurmaca metinlerde, en çok kullanılan tekniklerdendir. Bu teknik kullanılırken olaylar, kahramanların aralarında yaptıkları konuşmalardan anlaşılır. Diyalog metne akıcılık ve hareket katar, kahramanların psikolojik durumlarını gözler önüne serer.

“Gün Olur Asra Bedel” romanında, 86-112 sayfalar arasında yıldızlarla ayrılmış kısımlarda 6 tane diyalog tekniği kullanılmıştır. Așağıdaki örnekte verdiğimiz diyalog parçası, Kazangap ile askerlik şubesindeki görevli arasında geçmektedir. Kazangap askerliğe niçin çağırılmadığını öğrenmeye çalışmaktadır.

- Asanbayev Kazangap! Asanbayev kim? Sıradan çıkıp benimle gelsin!

- Kazangap söyleneni yaptı:

- Asanbayev benim.

- Ver bakayım belgeni. Tamam, sensin. Gel benimle.

İstasyonda, toplanma merkezine gittiler. Görevli ona:

- Sen geri dönüyorsun Asanbayev! Nereden gelmişsen oraya dön! Anladın mı? dedi. 
Demir, S. (2021). "Gün Olur Asra Bedel" romaninda hâldeki olaylarm olay örgüsüne nakşedilişi ve romanda anlatım tekniklerinin kullanılışı.

- Anladim. (Aytmatov, 2018, s. 91)

Romanın ilgili sayfaları arasında geçen bir diğer önemli diyalog örneği de Yedigey ile devesi Karanar'ın fotoğrafını çeken fotoğrafçılar arasında geçmektedir:

“- Demek bizim deve bir bakteryan?

- Hem de en saf cinsi, bir pırlanta!

- Peki ne diye ölçtünüz? Neye yarayacak o ölçüler?

- Bilimsel inceleme için" (Aytmatov, 2018, s. 96).

Bahsetmek istediğimiz son diyalog örneği de Yedigey ve Kazangap arasında geçen, demir yolunda çalışırlarken, şiddetli bir tipinin işleri zorlaştırması üzerinedir:

"Yedigey, eldiveni içinde donmuş parmaklarını birbirine vurarak:

- Kazake, dedi, artık yeter, lokomotife çıkalım da tipinin dinmesini bekleyelim.

- Havanın değişeceği yok, şimdi nasılsa yine öyle olacak, işimiz yolu açmak, nasıl olsa biz yapacağız bu işi”" (Aytmatov, 2018, s. 107).

Diyalog, roman kahramanları ile okuyucunun en yakın teması kurduğu metin parçalarıdır. $\mathrm{Bu}$ yönüyle ayrı öneme sahiptir. Bir roman boyunca daha birçok anlatım tekniği kullanılsa da diyalog olayı en basit, aracısız ve yalın hâliyle veren tekniktir.

\subsection{0. $\quad$ Iç çözümleme tekniği}

İç çözümleme tekniği, anlatıcının araya girmesi ve kahramanların duygu ve düşüncelerini okura anlatmaya başlaması şeklinde karşımıza çıkar. Edebî eserlerde bu teknik sıklıkla kullanılır. Bu teknik zaman zaman iç monolog ile karıştırılır. İç çözümleme tekniği, anlatıma gerçeklik katması yönünden de romanı güçlendiren bir unsurdur (Tekin, 2019, s. 272). İç çözümleme tekniğinde anlatıcının yansıttığı, kahramanın iç dünyasıdır. Fakat bunu araya girerek anlatıcı kimliği ile yapar. Anlatıcının varlığı o an hissedilir.

"Gün Olur Asra Bedel" romanında, 86-112 sayfalar arasında yıldızlarla ayrılmış kısımlarda 6 tane iç çözümleme tekniği kullanılmıştır.

"Eh, ne yapalım, gelirse gelsin, diye düşündü Yedigey. Onu geri yollamak için vakit kaybetmeye değmezdi" (Aytmatov, 2018, s. 105). Örnekte anlatıcı, cenazeyi gömmeye giderken onları takip eden köpek Yolbars için Yedigey'in zihninden geçenleri okuyucuya aktarmıştır. Örnekte görüldügüü gibi bu noktada anlatıcı yoktur, direkt olarak Yedigey'in hisleri vardır.

İç çözümleme tekniğinin kullanılmasına şu örnekleri de verebiliriz: "Yedigey bir an gözlerinin önüne kar yağışını, kar üzerinde bu kuşların uçuştuklarını getirdi. 'Yakında giderler... kar düşer düşmez toplanıp terk ederler buraları' diye düşündü’ (Aytmatov, 2018, s. 102).

"Yedigey'in aklından şunlar da geçiyordu: Allah'ın varlığına ya da yokluğuna inanmak başka şeydir. Ama insan denen yaratık, bu șekilde davranması bağışlanacak bir şey olmasa da ancak başı sıkıştı̆̆ı zaman Allah'ın adını anıyor, Allah'tan yardım diliyor" (Aytmatov, 2018, s. 108). Örneklerde görüldüğü gibi, yazar bu teknikle kahramanların içinden geçen duygu ve düşünceleri çözümler ve okuyucuya yansitır.

\subsection{1. İç monolog tekniği}

Kişinin kendi kendine konuşması anlamına gelen iç monolog tekniğinin kullanıldığı bölümler, konuşma diline yakındır, dil bilgisi kuralları göz ardı edilebilir. Çünkü insanın kendi kendine konuşması en doğal ve hazırlıksız konuşmadır (Tekin, 2019, s. 277). Yazar romanda iç monolog tekniğini kullanırken, anlatıcıyı aradan kaldırır. Okuyucu ile kahraman baş başadır. Okuyucu, kahramanın duygu ve düşüncelerini, kahramandan öğrenir. 
“Gün Olur Asra Bedel" romanında, 86-112 sayfalar arasında yıldızlarla ayrılmış kısımlarda 4 tane iç monolog tekniği kullanılmıştır.

“Öldükleri zaman, birbirlerini gömmek zorunda kaldıkları zaman ne yapacaktı bu insanlar? Öleni sonsuzluğa uğurlarken, hayatın başlangıcını ve sonunu kapsayacak sözleri nereden bulup söyleyeceklerdi" (Aytmatov, 2018, s. 108). Cenaze cemaatindeki hiç kimsenin, Kazangap'a okumak için bildiği bir dua olmadığını gören Yedigey içinden bunları geçirir. Bu insanlar öldüklerinde bir diğeri dua bilmeden ne yapacak diye kaygılanır. Neslin git gide gelenek-göreneklerini unutması Yedigey'i hüzünlendirir.

Yolbars isimli köpek cenaze alayını takip ederken, Yedigey'in içinden geçenlerde de iç monolog tekniğinin kullanıldığı kısımlar vardır: "Bir bu eksikti! Köyden çıkarlarken yoktu. Ne zaman katılmıştı peşlerine. Geleceğini bilse, bağlardı köpeği” (Aytmatov, 2018, s. 105).

İç monolog zaman zaman iç çözümleme tekniği ile karıştırıldığını söylemiştik. İç monolog tekniğinde kahraman ile okuyucunun iletişimi aracısız olarak gerçekleşir gibidir. Kahramanın zihninden geçenleri okuyucu direkt ondan öğrenir. İç çözümleme tekniğinde ise adı üzerinde anlatıcı kahramanın içini çözümler. Okuyucu kahramanın zihninden geçenlere anlatıcı vasıtasıyla hâkim olur.

\section{Sonuç}

Cengiz Aytmatov'un kişiliğinde ve sanat anlayışında, hayatının zor şartlarına rağmen, adı dünya çapında bilinmiş bir yazar olması büyük dikkat çekmektedir. Eserlerini kaleme alışında, eserlerinde işlediği konularda hep onun şahsına ait bir tarz vardır. Görülmektedir ki, kendi gibi olan, kendince anlatımı olan bir yazardır. Eserlerinde dönemin gerçeklerine 1şık tutarken, dilinin akıcılığı ve naifliğiyle de insanın kalbini 1sıtır. Eserlerinde bakış açısı olarak ötekileştirmeden barışçıl ve sevgi dolu bir yol izler. Kahramanlarını önce kendi sever, sonra okuyucuya sevdirir.

Biz çalışmamız boyunca Cengiz Aytmatov'un sanat anlayışını anlaşılır bir şekilde sunabilmeye gayret ettik. Ayrıca "Gün Olur Asra Bedel” romanında, yazarın olay örgüsünü nasıl kurguladığına ve anlatım tekniklerini nerelerde, nasıl ve ne amaçla kullandığına açıklık getirmeye çalıştık.

Romanda hâldeki olayların ana görüntüsü, örneklerde de belirttiğimiz gibi, özetle: Kazangap'ın ölüm haberinin alınması, Kazangap'ın vasiyetine uygun olarak Ana Beyit'e gömülmesi için yola çıkılması, cenazenin Ana Beyit'e gömülmesinin engele uğraması ve cenazenin, Nayman Ana'nın oğlu için gözyaşı döktüğü o vadiye, Malakumdıçap'a gömülmesidir.

Çalışmamızın "GİRIŞ̧" kısmında bahsettiğimiz hipotezlerin çoğuna açıklık getirdik. Anlatım tekniklerinin büyük bir kısmının kullanılması hususuna değinmemiz gerekirse, Aytmatov eserinde, anlatım tekniklerinin hemen hemen hepsini ustalıkla kullanmıştır. Bu teknikler; anlatma-gösterme, tasvir, mektup, özetleme, geriye dönüş, montaj, otobiyografi, leit motiv, diyalog, iç çözümleme ve iç monologdur. Sözü geçen bu teknikleri Aytmatov, romanın yapısına uygun bir şekilde yaymıştır. Anlatım teknikleri romanda sırıtmamış, tam da gerektiği gibi kullanılmıştır. Örneğin; karakterlerin dili nasıl kullandığını görebilmemiz için diyalogları, romana bir orijinallik katması ve coğrafyayı en güzel bir şekilde vermesi açısından leit motivleri, Kırgız insanının ruh dünyasının derinliklerine inip onları anlayabilmemiz için iç çözümleme ve iç monolog tekniklerini, en önemlisi romanın özünü oluşturan anlatma ve gösterme tekniklerini titizlikle kullanmıştır.

“Gün Olur Asra Bedel”, birkaç anlatım tekniğiyle tamamlanmış, basit bir alt yapı ve kurguya sahip bir eser değildir. Verdiğimiz örneklerde de görülmektedir ki; efsaneler, Kırgız gelenekleri, coğrafya koşulları, karakter analizleri, mektuplar vb. Aytmatov'un romanının besleyici unsurları olmuştur.

Hâldeki olayların, olay örgüsünün ana iskeletini oluşturması hususunun, bu roman için doğru bir tespit olduğunu düşünmekteyiz. Çünkü romandaki ana konu Kazangap'ın vefâtı ve gömülme hadisesidir. Olay örgüsü, hâldeki bu yolculuk ile şekillenir. Yazar, bu defin yolculuğunun hazırlık sürecinde, yolculuk esnasında ve sonucunda; bazen Yedigey'in düşünceleri ile bazen de geriye dönüp 
Demir, S. (2021). "Gün Olur Asra Bedel" romaninda hâldeki olaylarm olay örgüsüne nakşedilişi ve romanda anlatım tekniklerinin kullanılışı.

geçmişte yaşananları vererek olay örgüsünü oluşturmuş̧tur. Yani olay örgüsünün ana iskeleti olan hâldeki olayları, böylece roman boyunca beslemiştir.

Bir diğer hipotezimiz olan Aytmatov'un yaşadığı coğrafyayı eserinde yansıtması hususuna gelecek olursak; Aytmatov, kendisinin de yaşadığı ve memleketi olan Kırgız coğrafyasını gerek mekân tasvirleriyle gerek olay örgüsüne yedirerek çok güzel bir şekilde yansıtmayı başarmış bir yazardır. Mekân romanda, hiçbir zaman olay örgüsünden bağımsız kalmamış hep onunla ilerlemiştir. Mevsimler değişmiş, ortam koşulları değişmiş ve yazar bunu okuyucuya hep yaşatmıştır.

Çalışmamızın elbette eksiklikleri bulunabilir ve bunlar geliştirilebilir. Biz ele aldığımız konuyu en açıklayıcı bir şekilde sunmaya çalıştık. Anlatım tekniklerinin incelenmesi hususunda koşullar gereği bir örneklem seçildi. Anlatım tekniklerinin romanın bütününü dikkate alan bir dağılımının ortaya konması, ulaştığımız sonuçları zenginleştirecektir.

\section{Araştırmanın etik yönü}

Yapılan bu çalışmada "Yükseköğretim Kurumları Bilimsel Araştırma ve Yayın Etiği Yönergesi" kapsamında uyulması belirtilen tüm kurallara uyulmuştur. Yönergenin ikinci bölümü olan "Bilimsel Araştırma ve Yayın Etiğine Aykırı Eylemler" başlığı altında belirtilen eylemlerden hiçbiri gerçekleştirilmemiştir. Bu araştırmanın etik kurul izni gerektirmeyen araştırmalardan olduğunu beyan ederim.

\section{7. Çıkar çatışması beyanı}

Bu çalışmada, sonuçları veya yorumları etkileyebilecek herhangi bir maddi veya diğer asli çıkar çatışması olmadığını beyan ederim.

\section{Katkı Oranı}

Çalışmanın tüm aşamaları yazar tarafından tasarlanmış ve hazırlanmıştır.

\section{KAYNAKÇA}

Ağır, A. (2013). Cengiz Aytmatov'un Gün Olur Asra Bedel'inde kimlik oluşturma süreçleri. Bilig, 65,

$$
01-22 \text {. }
$$

Aktaş, Ş. (2003). Roman sanatı ve roman incelemesine giriş. Akçağ Yayınları.

Aytmatov, C. (2018). Gün olur asra bedel. (58. bask1). Ötüken Yayınlar1.

Birinci, N., Yavuz, K., \& Yetiş, K. (2006). Türk dili ve kompozisyon. Bayrak Basım Yayım.

Çağlar, A. (2018, Aralık 18). Asra bedel olan o güne bir bakış bir görüş. Yeni Ufuk Dergisi, https://www.yeniufukdergisi.com/2018/12/18/asra-bedel-olan-o-gune-bir-bakis-bir-gorus/

Çetişli, İ. (2004). Metin tahlillerine giriş 2. Akçağ Yayınları.

Develioğlu, F. (2015). Osmanlıca-Türkçe ansiklopedik lügat. (31. baskı). Aydın Kitabevi Yayınları.

Dıykanbayeva, M. (2015). Hatıralar ışığında Cengiz Aytmatov ve eserleri. Uluslararası Türkçe 
Kayseri Üniversitesi Sosyal Bilimler Dergisí Ciltt 3, Sayi: 1, Haziran 2021, 24-40

Kayseri University Journal of Social Sciences. Vol 3, No: 1, June 2021, 24-40

Edebiyat Kültür Eğitim Dergisi, 4(1), 169-188. https://doi.org/10.7884/teke.362

Durmaz, R. (2007). Tanrı dağları'nın karlı doruklarından Aral gölüne akan ırmak; Cengiz Aytmatov.

Türk Dünyası Dil ve Edebiyat Dergisi, (24), 55-63.

Forster, E. M. (2014). Roman sanatı. (Ü. Aytür, Çev.). Milenyum Yayınları.

İstanbul Aydın Üniversitesi (2018, Kasım 9). Doğumunun 90. yılında Cengiz Aytmatov töreni [Video].

Youtube. https://www.youtube.com/watch?v=vvR91Wyiow8

Kahraman, A. (2016). Aytmatov, Cengiz. Türkiye Diyanet Vakfi İslam Ansiklopedisi, Ek-1, 148-150.

https://islamansiklopedisi.org.tr/aytmatov-cengiz

Özyer, N. (1993). Edebî tür olarak otobiyografi ve iki örnek. Hacettepe Üniversitesi Edebiyat Fakültesi Dergisi, 10(1), 73-85.

Tekin, M. (2019). Roman sanatı 1, romanın unsurları. (17. baskı). Ötüken Yayınları.

Tulum, M. M. (2014). Cengiz Aytmatov'un ismi üzerine. Türkiyat Mecmuası, 24, Bahar, 91-97.

Tuzman, U. (2009, Ocak 5). Kurgızistan Ata-Beyit Katliamı. https://yenidenergenekon.com/352kirgizistan-ata-beyit-katliami/

Türk Dil Kurumu. (t.y.). Otobiyografi. İçinde Güncel Türkçe sözlük. Erişim tarihi: Haziran 22, 2021, https://sozluk.gov.tr/

Yılmaz, A. (1998). Cengiz Aytmatov'da eser-biyografi ilişkisi. Türk Edebiyatı Aylık Fikir ve Sanat Dergisi, 299, 48-49.

Yılmaz, D. (2011). Roman sanatı ve toplum. Kesit Yayınları. 